\title{
Pengaruh Lemahnya Pelaksanaan Supervisi Pendidikan terhadap Hasil Belajar
}

\author{
Siswa \\ Meldiya Kismonia Chanda \\ meldiyakismonia2598@gmail.com
}

\begin{abstract}
ABSTRAK
Peningkatan mutu pendidikan berkaitan erat dengan usaha peningkatan kematangan dan kemampuan profesional guru dalam pembelajaran yang nantinya mampu mengantisipasi tantangan-tantangan dalam pendidikan. Mutu pendidikan sangat tergantung pada komponen-komponen yang terdapat dalam pendidikan, diantara komponen yang sangat mempengaruhi berhasil tidaknya pendidikan adalah tergantung dari kualitas guru. Guru yang profesioanal adalah guru mampu berdedikasi dengan semua elemen yanga da baik dengan siswa, guru alinnya, tenaga kependidikan lainnya, kepala sekolah dan masyarakat lainnya, dan pastinya adalah guru yang ahli dibidangnya dan berlatarbelakang dari pendidikan. Oleh karena itu, guru merupakan faktor penentu bagi keberhasilan nproses belajar mengajar didalam lembaga pendidikan.

Metode yang digunakan dalam tulisan ini adalah studi pustaka, yang mana penulis membaca dari berbagai literatur atau sumber bacaan baik itu buku, e-journal, dan literaturliteratur pendudukang lainnnya. Tulisan ini bertujuan untuk menjawab realita yang terjadi ditengah-tengah masyrakat terutama disekolah bagaiamana pengaruh lemahnya pelaksanaan suprvisi pendidikan terhadap hasil belajar siswa.
\end{abstract}

Kata kunci: Profesional, Supervisi Pendidikan, Mutu Pendidikan

\section{Latar Belakang}

Pendidikan merupakan aset utama suatu bangsa dan sangat penting dalam kelangsungan hidup bangsa. Pendidikan berkualitas sangatlah diperlukan dalam usaha untuk kemajuan bangsa dan negara. Sebagaimana disebutkan dalam Undang-Undang Sistem Pendidikan Nasional No. 20/2003, bahwa pendidikan merupakan usaha sadar dan terencana untuk mewujudkan suasana belajar dan proses pembelajaran agar peserta didik secara aktif mengembangkan potensi dirinya untuk memiliki kekuatan spritual keagamaan, pengendalian diri, kepribadian, kecerdasan, akhlak mulia, serta keterampilan yang diperlukan dirinya masyarakat, bangsa, dan negara. Sedangkan visi pendidikan nasional adalah terwujudnya sistem pendidikan nasional yang dapat memberdayakan semua warga negara Indonesia berkembang menjadi manusia yang berkualitas sehingga mampu dan proaktif menjawab tantangan zaman. Karena itulah dewasa ini pendidikan menghendaki sistem pendidikan yang mampu meningkatkan mutu pendidikan, moral dan kualitas sumber daya manusia.

Peningkatan mutu pendidikan berkaitan erat dengan usaha peningkatan kematangan dan kemampuan profesional guru dalam pembelajaran yang nantinya mampu mengantisipasi tantangan-tantangan dalam pendidikan. Mutu pendidikan sangat tergantung pada komponen-komponen yang terdapat dalam pendidikan, diantara komponen yang sangat mempengaruhi berhasil tidaknya pendidikan adalah tergantung 
dari kualitas guru. Oleh karena itu pemerintah mengambil kebijakan menerbitkan UU No.14 tahun 2005 tentang guru dan dosen, yang pada intinya meningkatkan kualitas guru dan dosen. Guru yang profesioanal adalah guru mampu berdedikasi dengan semua elemen yanga da baik dengan siswa, guru alinnya, tenaga kependidikan lainnya, kepala sekolah dan masyarakat lainnya, dan pastinya adalah guru yang ahli dibidangnya dan berlatarbelakang dari pendidikan. Oleh karena itu, guru merupakan faktor penentu bagi keberhasilan proses belajar mengajar didalam lembaga pendidikan. Supervisi adalah proses pelayanan untuk membantu dan membina guru-guru, pembinaan ini nantinya menyebabkan perbaikan dan peningkatan keprofesionalan guru. Dalam hal ini kepala sekolah berkewajiban membantu guru serta memberi dukungan agar dapat melaksanakan tugas dengan baik sebagai pendidik maupun pengajar. Karena fungsi utama supervisi pendidikan adalah ditujukan pada perbaikan dan peningkatan kualitas pengajaran. Tetapi fakta yang terjadi hari ini, supervisi pendidikan disekolah baik itu yang berhubungan dengan guru, staf ahli, maupun kepala sekolah tidak berjalan sebagaimana mestinya.

Dari uraian diatas terdapat rumusan masalah dari tulisan ini yaitu bagaimana pengaruh supervisi disekolah terutama keprofesionalan guru terhadap hasil belajar siswa. Kemudian adapun tujuan dari tulisan ini yaitu tulisan ini mampu menjelaskan bagaimana pengararuh supervisi pendidikan terutama keprofesional guru dalam mengajar terhdap hasil belajar siswa.

\section{Pembahasan}

\section{Pelaksanaan supervisi disekolah}

Pelaksaanaan supervisi pendidikan disekolah tidak berjalan sebagaimana mestinya. Supervisi adalah kegiatan pengontrolan dan pengawasan yang dilakukan oleh kepala sekolah sebagai seorang pimpinan dalam sebuah lembaga, disini tugas dan kewajiban kepala sekolah adalah mengontrol dan membimbing para guru dalam proses pembelajaran, sehingga dengan adanya bimbingan dan bantuan dari kepala sekolah dapat meningkat keprofesionalan seorang guru. Dikemukakan oleh sabandi (Sabandi, 2013) Supervisor memegang peranan penting dalam meningkatkan kualitas guru agar dapat melaksanakan pembelajaran yang lebih berkualitas. Jabatan supervisor di sekolah meliputi kepala sekolah dan pengawas. Supervisi yang dilakukan oleh kepala sekolah diatur dalam Permen Diknas Nomor 13 Tahun 2007 tentang Standar Kepala Sekolah/Madrasah. Dimensi kompetensi supervisi kepala sekolah yang meliputi: (1) merencanakan program supervisi akademik dalam rangka peningkatan profesionalisme guru, (2) melaksanakan supervisi akademik terhadap guru dengan menggunakan pendekatan dan teknik Pelaksanaan supervisi disekolah sering kali tidak tepat sasaran atau sering mengalami penyelewengan-penyelewengan dalam menjalankannya. Salah satu faktor supervisi tidak berjalan dengan baik adalah salah satunya masalah sertifiksi guru. Sertifikasi guru adalah proses pemberian sertifikat pendidik kepada guru. Sertifikat pendidik diberikan kepada guru yang telah memenuhi standar profesional guru. Guru profesional merupakan syarat mutlak untuk menciptakan sistem dan praktik pendidikan yang berkualitas. Dari penggertian diatas sertifikasi guru tujuan nya sangat bagus sekali yaitu untuk mencapai tujuan pendidikan nasional, tetapi realita nya guru-guru yang sertifikasi tidak menjalankan yang semestinya dijalankan. Guru yang mendapatkan sertifikasi ini kan mendapatkan tunjungan fungsional dan semua guru sertifikasi harus maksimal jam mengajar nya 
dalam satu minggu. Misalnya seorang guru sertifikasi mengajar 24 jam dalam satu minggu, ketika sang guru mengajar sosiologi dan guru sosiologi pun ada beberapa orang dan jam nya harus dibagi rata sehingga guru-guru sertifikasi tadi harus mengambil jam dengan mata pelajran yang berbeda misalnya seni budaya agar jam nya dapat terpenuhi. Fenomena seprti ini bukan lah dapat meningkatkan mutu pendidikan tetapi dapat menjatuh mutu pendidikan karena sudah tidak ada adanya keprofesionalan guru dalam mengajar. Guru tidak lagi mengajar sesuai dnegan bidang keahliannya tapi juga mengajar yang bukan keahliannya yang secara tidak langsung guru pun kurang paham dengan materi yanga kan ia berikan kepada peserta didik.

\section{Pengaruh profesional guru terhadap hasil belajar siswa}

Keprofesional seorang guru sangat mennetukan hasil belajar siswa bahkan mutu pendidikan. Seorang guru yang memang ahli dibidang nya ia pasti akan nyaman dan senang mengajarkan suatu ilmu kepada peserta didiknya karena sesuai dengan ilmu yang ia miliki, tetapi hari ini malah sebaliknya sangat banyak sekali guru mengajar tidak sesuai dengan idang keahlian nya, tidak dapat penulis pungkuri bahwa ini terjadi disekolah penulis sendiri bahwasannya masih banyak guru yang tidak mengajar sesuai dengan bidang keahliannya. Fenomena seperti ini tentu jauh dari tujuan pendidikan nasional yang kita dambakan.

\section{Penutup}

\section{Kesimpulan}

Berdasarkan pembahsan diatas disimpulkan bahwa Supervisi pendidikan adalah sesuatu kegiatan pengawasan dan pengontrolan yang dilakukan oleh kepala sekolah. Surpervisi yang dijalan dengan baik akan berpengaruh pada keprofesionalan guru. Ketika, guru sudah dapat dikatakan profesional baik sebagai tenaga pendidik, maupun hubungan nya sesama dan guru dan kepala sekolah telah berjalan dengan baik sehingga supervisi pendidikan dapat meningngkat mutu pendidikan nasional.

\section{Saran}

Penulis berharap semoga regenarasi guru berikut yang sudah paham dengan supervisi pendidikan ini dapat menjalankan sebagaimana mestinya, dan profesinal lah menjadi seorang guru, karena guru sejatinya tugas adalah mendidik dan gurulah yang akan melahirkan generasi-generasi hebat bangsa ini.

\section{Referensi}

http://eprints.ums.ac.id/40572/2/BAB\%20I.pdf

http://repository.iainpurwokerto.ac.id/1052/1/Cover_Bab\%20I_Bab\%20V_Daftar\%20Pus $\underline{\text { taka.pdf }}$

Sabandi, A. (2013). supervisi pendidikan untuk pengembangan profesionalitas guru berkelanjutan. Pedagogi Jurnal Ilmiah Ilmu Pendidikan, XIII(2), 1-9. Retrieved from http://ejournal.unp.ac.id/index.php/pedagogi/article/view/4275 
